\title{
Release of three improved varieties for the expanded potato market in Kenya
}

\author{
Onditi J.O', S.W.K Nderitu', J.A. Landeo ${ }^{2}$, G. O. Abong', ${ }^{\text {, }}$ E. O. Sikinyi ${ }^{3}$ and J.N. Kabira ${ }^{1}$ \\ ${ }^{1}$ Kenya Agricultural Research Institute (KARI), Tigoni P. O. Box 338-00217 Limuru, Kenya \\ ${ }^{2}$ International Potato Centre (CIP), Sub-Saharan Africa Office Nairobi. P.O. Box 25171, \\ Nairobi, Kenya \\ ${ }^{3}$ Kenyan Plant Health Inspectorate Service (KEPHIS), P. O. Box 49592-00100 Nairobi, \\ Kenya; (current address, Seed Trade Association of Kenya -STAK, P. O. Box 2581- 00202 \\ Nairobi Kenya) \\ ${ }^{4}$ University of Nairobi, Department of Food Science, Nutrition and Technology, P. O. Box \\ 29053, Nairobi, Kenya.
}

\section{Corresponding Author: Email: john3oju@yahoo.com ABSTRACT}

\begin{abstract}
Current potato varieties have not fully met the market demands of the rapidly expanding Kenyan potato industry. Newer varieties with tolerance to the major diseases, higher yields, better storability and processing qualities are therefore required. Through a collaborative research, six promising late blight tolerant clones initially from the International Potato Centre (CIP) were evaluated in National Performance Trials (NPT) in six potato growing regions. Three clones, namely: $393385.39,393371.58$ and 391691.96 were released by the National Variety Release Committee (NVRC) under the respective names of Sherekea, Kenya Mpya and Purple Gold. Sherekea had high yields (40-50T/ha), high tolerance to late blight and to major viruses, attractive red skin color, good storability, good cooking and processing qualities. Kenya Mpya had high yields (35-45 T/ha), high resistance to late blight, good chipping and mashing quality, short dormancy (75-90 days), early tuber bulking and early physiological maturity (90-105 days). Purple Gold had moderate to high yields, excellent crisping and good chipping, Table, cooking and mashing qualities, long dormancy and very good storability. The new varieties are expected to respond to various demands of the potato industry while increasing the varietal options available to the farmers.
\end{abstract}

Key words: Solanum tuberosum, variety, market, Kenya

\section{INTRODUCTION}

Potato (Solanum tuberosum L.) in Kenya is the second most important food and cash crop after maize (MoA/GTZ-PSDA, 2009). The crop makes a significant contribution to food security and is a major income earner among small scale growers in the highlands (above 1800 m.a.s.l) growing areas. Grown by more than 800,000 potato farmers, the crop also plays an important role in employing over 2.5 million people indirectly as market agents, transporters and processors. The increasing high demand for the potato in the country is due to population growth, urbanization, tourism and export of processed products (MoA, 2005). The national average potato yields are below (10 T/ha) due to several production constraints, the most important being lack of improved varieties and poor seed quality of most traditional varieties and marginal availability of certified seed from the few recently released varieties (MoA/GTZ-PSDA, 2009).

The search for high yielding, disease and pest tolerant varieties with market demanded traits has remained a major challenge to breeders since introduction of the crop over a century ago (NPRC, 2008). In the recent past, the major focus in potato improvement in Kenya has been the development of potato varieties with resistance to late blight (Pytophthora infestans), high tuber yields, early maturity, good storability and improved processing qualities into value added products (MoA, 2005). In collaboration with the International Potato Center (CIP), several high yielding varieties were released, including Tigoni and Asante in 1998 followed by Kenya Sifa, Kenya Karibu, Kenya Faulu and Kenya Mavuno which were released in 2002 (Lungaho et al., 2006). These varieties are yet to meet the ever 
increasing demands from the diverse stakeholders due to the fact that each consumer has their preferences depending on identified market niches (MoA/GTZ-PSDA, 2009). Delay in the release and slow diffusion of the new varieties in the past has unfortunately led to the informal introduction of exotic varieties from neighboring countries that gain quick popularity within the farming community (MoA/GTZPSDA/CIP/USAID, 2009).

Potato late blight is the most constraining disease in potato production worldwide (Fry et al., 2001; Turkesteen and Flier, 2002). One hundred percent yield loss may be recorded in uncontrolled field late blight epidemics or when extensive tuber infection and subsequent deterioration occurs in storage (Stevenson, 1993). Recent evaluations on both improved varieties and old farmers' varieties indicate that many of the popular varieties in Kenya do not have durable resistance to late blight (Lung'aho et al., 2008). Yield losses attributed to late blight in Kenya have been reported to be about $40-50 \%$ (Olanya et al., 2001) and later $20-80 \%$ depending on the varieties and prevailing weather conditions (Lung'aho et al., 2006; Lung'aho et al., 2008). Development, maintenance and utilization of disease resistant varieties are considered a sustainable long term solution to yield reductions resulting from such disease infections (Simons, 1972; Khurana, 2000).

Breeders at CIP have developed a new potato breeding population (population B) with high level of partial resistance to late blight, in absence of known major (dominant) $\mathrm{R}$ genes (Landeo et al., 1997). Resistance emphasizes on quantitatively inherited genes, more commonly known as minor genes. This breeding strategy that started in the 1990's resulted in the selection of advanced clones that were distributed to the developing countries worldwide for testing and selection of new resistant varieties. Many of these clones were distributed to Sub Saharan Africa (SSA) countries and have been evaluated by many countries (including Kenya) where dozens of new varieties were released successfully (El-Bedewy et al., 2001; Lungaho et al., 2006). Varieties with such durable resistance have been reported to significantly reduce the amount of fungicide sprays (Nakitandwe et al., 2005) and this is expected to bring about economical and environmentally friendly way of growing potatoes especially by the small scale farmers.

During the breeding and improvement process at CIP, suitable agronomic traits, tolerance to abiotic and biotic stresses, early tuberization and bulking,
Table and processing qualities as well as adaptation to a wide range of agro-ecological environments are taken into account (Landeo et al., 2000; Nakitandwe et al., 2005). The aim of this study was identify suitable clones for release as high yielding varieties with value added characters and to ensure such desirable traits are utilized for the benefit of the potato industry in Kenya,

\section{MATERIALS AND METHODS}

Twenty six potato clones from advanced breeding population with durable resistance to late blight were obtained from CIP, Lima Peru. The clones were respectively evaluated in the multilocational trials (MLT) in diverse agro-ecological zones (AEZ) for four consecutive years (2004-2007). Out of these, six superior clones $(392617.54,392657.8,393385.39$, $385524.9,393371.58$ and 391691.96) were identified as promising for potential release as varieties and were subsequently submitted to the national performance trials (NPT) in the long (LR) and short growing (SR) seasons of 2009. The NPT was conducted under the coordination of KEPHIS in collaboration with CIP and KARI, Tigoni. The seed potatoes for all experiments were obtained from disease free seed lots at KARI Tigoni. The experimental materials included the 6 clones and 2 improved local varieties Tigoni and Dutch Robjin as checks. The pedigrees of the clones are as follows: $391691.96=385021.12 \times \mathrm{XY} .16 ; 392657.8=$ $387341.1 \times 387170.9 ; 393371.58=387170.16 \times$ $387170.9 ; \quad 392617.54=387002.11 \times 387170.9$; $393385.39=387231.7 \times 387170.9$ and $385524.9=$ 380475.4 x BK.

The NPT was conducted in six locations situated in major potato growing areas namely: Tigoni (Limuru), Tendwet (Narok), Baraka-Agricultural Training College (Molo), Ol Joro Orok (Nyandarua), Kisima Farm (Timau) and Kibirichia (Meru). The clones were planted in randomized complete block design with four replication of 40 hills per plot. Each plot consisted of four rows with 10 plants each at the spacing of $85 \mathrm{~cm}$ between rows and $30 \mathrm{~cm}$ between plants. Fertilizer (Di-Ammonium Phosphate- \% N: P: $\mathrm{K}$ 18-46-0) was applied at planting at the rate of 100 $\mathrm{g}$ per row. Aphids (virus vectors) were controlled by applying Duduthrin1.75 EC, Lambda-cyhalothrin 17.5 $\mathrm{g} / \mathrm{l}$ at every appearance of the insect pest. Late blight was controlled by using two sprays with Dithane M45 (contact fungicide, wettable powder $80 \%$ Mancozeb; $2.0 \mathrm{~g} / \mathrm{l})$ sprayed at the appearance of the first symptoms of late blight infection followed by Ridomil gold (systemic fungicide, wettable powder 64\% Mancozeb; 4\% Metalaxil; $2.5 \mathrm{~g} / \mathrm{l}) 14$ days later. 
Weeding and earthing up were done during the growth of the crop following recommended practices (Kabira et al., 2006).

Reaction to late blight was assessed visually and was calculated using the values of area under disease progress curve (AUDPC) from percentage midpoint rule (Campbell and Madden, 1990)

as per the formula:

AUDPC $=\sum_{i=1}^{n-1}\left\{\frac{Y_{i}+Y_{i+1}}{2}\right\}\left(X_{i+1}-X_{i}\right)$, where,

$Y_{\mathrm{i}}=$ percentage (\%) of blighted leaf area on the $i^{\text {th }}$ observation,

$=$ the date of observation in days after planting and

$n=$ the number of disease severity readings.

Genotypes with lower AUDPC values were considered more tolerant to late blight and those with higher values as less tolerant. Harvesting was carried out at 120 days after crop emergence. Data collected on harvested tubers included tuber weight and number of tubers per plot. Tubers were also evaluated for cooking and sensory characteristics. Evaluation for chipping, crisping and boiling qualities was done at KARI Tigoni in collaboration with the University of Nairobi's Food Science Department and at Deepa Industries Limited in Nairobi. Data collected was subjected to ANOVA using GENSTAT software (Lawes, 1995). The differences between the means were compared using least significant difference (LSD) test at $\mathrm{P}=0.05$ (Steel and Torrie, 1980).

\section{RESULTS}

Yield performance: There were variations in tuber yield performance of the genotypes across different sites and seasons. The 4 highest yielders during the 2009 LR season (Table 1) were 392657.8 (29.8T/ha),
393385.39 (28.5 T/ha), 385524.9 (27.7 T/ha) and $393371.58(27.3 \mathrm{~T} / \mathrm{ha})$. They all out yielded the check variety Tigoni $(26.0 \mathrm{~T} / \mathrm{ha})$. During the $\mathrm{SR}$ season (Table 2), the 3 highest yielding clones were 393385.39 (36.2 T/ha), 385524.9 (35.0 T/ha) and $393371.58(30.2 \mathrm{~T} / \mathrm{ha})$. The best yield performance was realized at Tigoni during the LR 2009 with a mean yield of $40.0 \mathrm{~T} / \mathrm{ha}$ followed by Molo (34.2 T/ha), Narok (24.4 T/ha), Nyandarua (19.7 T/ha), Timau (19.5 T/ha) and the lowest was Kibirichia with 12.8 T/ha while during the SR 2009, the genotypes performed best at Nyandarua (42.8T/ha) followed by Tigoni (32.1 T/ha), Timau (28.4 T/ha), Narok (27.4 T/ha), Molo (19.0 T/ha) and Kibirichia (18.8 T/ha).

Tolerance to late blight: Genotypes with higher levels of tolerance to late blight were identified (Table 3). Clone 393385.39 was the most tolerant. It had low AUDPC values ranging from 99.6 to 296.4 with a mean of 198.0. The other two recommended clones namely: 391691.96 and 393371.58 were significantly $(P \leq 0.05)$ similar to variety Tigoni. All the test clones were however significantly $(P \leq 0.05)$ more tolerant to late blight than the most susceptible check variety (Dutch Robjin). There were significantly $(P \leq 0.05)$ higher late blight infection levels in the crop during the LR than the SR seasons where the respective mean AUDPC values were 662.2 and 360.1.

Cooking and processing quality: Three clones namely: $393385.39,393371.58$ and 391691.96 had extremely good chipping qualities (Table 4). Chipping quality of these clones was equal to that of Tigoni, currently the most popular chipping variety. The three clones also compared favorably with Dutch Robjin which is the leading in boiling and mashing quality. Clone 391691.96 significantly $(P=0.05)$ outperformed Dutch Robjin in quality. All clones evaluated had acceptable dry matter content.

Table 1: Tuber yield (T/ha) during long rains season ${ }^{1}$ in six trial sites

\begin{tabular}{|l|c|c|c|c|c|c|c|}
\hline Clone/ Variety & Tigoni & Kibirichia & Nyandarua & Timau & Narok & Molo & Mean \\
\hline 392657.8 & 47.4 & 16.3 & 24.3 & 21.8 & 27.5 & 41.4 & 29.8 \\
\hline 393385.39 & 47.8 & 10.1 & 17.9 & 27.5 & 29.4 & 38.5 & 28.5 \\
\hline 385524.9 & 37.8 & 13.5 & 27.7 & 23.3 & 27.7 & 36.3 & 27.7 \\
\hline 393371.58 & 51.7 & 13.0 & 17.7 & 16.0 & 29.4 & 36.0 & 27.3 \\
\hline 392617.54 & 37.1 & 17.2 & 15.9 & 16.9 & 17.9 & 25.0 & 21.7 \\
\hline 391691.96 & 42.4 & 10.5 & 16.9 & 14.2 & 16.2 & 28.9 & 21.5 \\
\hline Tigoni (check) & 35.5 & 9.8 & 19.4 & 20.6 & 31.6 & 39.0 & 26.0 \\
\hline Dutch Robjin (check) & 20.6 & 12.3 & 17.9 & 16.2 & 15.9 & 28.2 & 18.5 \\
\hline Mean & $\mathbf{4 0 . 0}$ & $\mathbf{1 2 . 8}$ & $\mathbf{1 9 . 7}$ & $\mathbf{1 9 . 5}$ & $\mathbf{2 4 . 4}$ & $\mathbf{3 4 . 2}$ & $\mathbf{2 5 . 1}$ \\
\hline LSD(5\% level) & $\mathbf{1 0 . 0}$ & $\mathbf{5 . 3}$ & $\mathbf{4 . 2}$ & $\mathbf{4 . 1}$ & $\mathbf{4 . 2}$ & $\mathbf{6 . 9}$ & $\mathbf{5 . 8}$ \\
\hline
\end{tabular}

${ }^{1}$ April to June 
Table 2: Tuber yield (T/ha) during short rains season ${ }^{2}$ in six trial sites

\begin{tabular}{|l|c|c|c|c|c|c|c|}
\hline Clone/ Variety & Tigoni & Kibirichia & Nyandarua & Timau & Narok & Molo & Mean \\
\hline 393385.39 & 43.8 & 20.8 & 60.0 & 31 & 33.8 & 27.8 & 36.2 \\
\hline 385524.9 & 39.8 & 20.8 & 45.5 & 39.7 & 33.3 & 31.0 & 35.0 \\
\hline 393371.58 & 40.5 & 20.8 & 38.0 & 29.5 & 35.8 & 16.5 & 30.2 \\
\hline 392657.8 & 27.2 & 20.8 & 37.8 & 26.0 & 26.0 & 17.3 & 25.8 \\
\hline 392617.54 & 20.8 & 12.5 & 46.0 & 28.4 & 17.0 & 17.5 & 23.7 \\
\hline 391691.96 & 18.2 & 14.8 & 30.0 & 17.5 & 17.0 & 11.0 & 18.1 \\
\hline Tigoni (check) & 41.5 & 21.5 & 41.8 & 33.4 & 32.8 & 18.5 & 31.6 \\
\hline Dutch Robjin (check) & 25.0 & 18.8 & 43.0 & 21.6 & 24.0 & 12.5 & 24.1 \\
\hline Mean & $\mathbf{3 2 . 1}$ & $\mathbf{1 8 . 8}$ & $\mathbf{4 2 . 8}$ & $\mathbf{2 8 . 4}$ & $\mathbf{2 7 . 4}$ & $\mathbf{1 9 . 0}$ & $\mathbf{2 8 . 1}$ \\
\hline LSD(5\% level) & $\mathbf{5 . 9}$ & $\mathbf{3 . 8}$ & $\mathbf{6 . 5}$ & $\mathbf{5 . 7}$ & $\mathbf{8 . 5}$ & $\mathbf{6 . 1}$ & $\mathbf{6 . 1}$ \\
\hline
\end{tabular}

${ }^{2}$ October to November

Table 3: Reaction of potato clones to natural infection by late blight during short and long rainy seasons, 2009 at KARI Tigoni

\begin{tabular}{|l|c|c|c|}
\hline Clone/ Variety & \multicolumn{3}{|c|}{ Mean AUDPC ${ }^{\mathbf{1}}$ values } \\
\hline & LR $^{\mathbf{2}} \mathbf{2 0 0 9}$ & SR $^{\mathbf{3}} \mathbf{2 0 0 9}$ & Overall mean \\
\hline 393385.39 & 296.4 & 99.6 & 210.1 \\
\hline 392617.54 & 319.1 & 101.0 & 440.3 \\
\hline 391691.96 & 555.6 & 325.0 & 444.2 \\
\hline 392657.8 & 605.1 & 283.2 & 541.0 \\
\hline 393371.58 & 732.5 & 349.4 & 559.7 \\
\hline 385524.9 & 778.2 & 341.2 & 459.8 \\
\hline Tigoni (check) & 595.4 & 324.1 & 1236.0 \\
\hline Dutch Robjin(check) & 1415.0 & 1057.0 & $\mathbf{5 1 1 . 1}$ \\
\hline Mean & $\mathbf{6 6 2 . 2}$ & $\mathbf{3 6 0 . 1}$ & $\mathbf{1 7 6 . 3}$ \\
\hline LSD(5\% level) & $\mathbf{2 1 6 . 3}$ & $\mathbf{1 0 1 . 4}$ & \\
\hline
\end{tabular}

${ }^{1}$ Area under disease progress curve; ${ }^{2}$ Long rains and ${ }^{3}$ Short rains

Table 4: Cooking and processing quality of NPT entries

\begin{tabular}{|l|c|c|c|c|}
\hline Clone/ Variety & $\begin{array}{c}\text { Dry matter (\%) } \\
\text { content }^{1}\end{array}$ & $\begin{array}{c}\text { Chipping } \\
\text { quality }^{2}\end{array}$ & $\begin{array}{c}\text { Crisping } \\
\text { quality }^{\mathbf{3}^{2}}\end{array}$ & $\begin{array}{c}\text { Boiling and } \\
\text { mashing quality }^{2}\end{array}$ \\
\hline 385524.9 & 22.7 & 5 & 2.42 & 4 \\
\hline 392657.8 & 22.1 & 6 & 2.42 & 5 \\
\hline 392617.54 & 21.1 & 5 & 1.85 & 6 \\
\hline 393385.39 & 21.9 & 8 & 2.92 & 8 \\
\hline 393371.58 & 22.5 & 8 & 2.56 & 8 \\
\hline 391691.96 & 23.4 & 8 & 1.21 & 8 \\
\hline Tigoni (check) & 21.2 & 8 & 1.67 & 7 \\
\hline Dutch Robjin (check) & 22.7 & 6 & 2.42 & 8 \\
\hline Mean & $\mathbf{2 2 . 2}$ & $\mathbf{6 . 4}$ & $\mathbf{2 . 2}$ & $\mathbf{6 . 7}$ \\
\hline LSD (5\%) & $\mathbf{2 . 9}$ & $\mathbf{1 . 1}$ & $\mathbf{0 . 9}$ & $\mathbf{0 . 9}$ \\
\hline
\end{tabular}

'Dry matter content of $20 \%$ and above was acceptable

${ }^{2}$ Chipping, boiling and mashing quality scores was on a hedonic scale of 1-9 where 1 was extremely poor and 9 was extremely good. A score of 5 and above was acceptable.

${ }^{3}$ Crisping quality was on a scale of 1-5 where 1 was excellent and 5 very poor. A score of 2.5 and below was acceptable al. 


\section{DISCUSSIONS}

Variety Sherekea (393385.39): Tubers of Sherekea are round in shape with medium to deep eye depth and attractive red skin colour. The new potato variety is a medium sized potato plant (intermediate between tuberosum and andigena) with strong semi erect stems, dark green small to medium-sized leaves, light purple flower colour and regular flowering habit. The sprouts under diffused light storage (DLS) are red-violet and are produced in 80-100 days (medium dormancy). Sherekea is adapted to wide range of environments but for optimum productivity, an altitude range of between 1800-3000 m.a.s.I is most suitable. Among the Kenyan potato varieties, Sherekea produces the highest range of yield of between 40-50 T/ha under optimum growing conditions compared to other high yielding varieties like Tigoni, Asante, Kenya Sifa , Kenya Karibu, Kenya Faulu and Kenya Mavuno which produce between 35-45 T/ha under the same conditions (Lungaho et al.,2006). The crop bulks ware size tubers at between 90-100 days (early) but reaches full physiological maturity at 105120 days. Early tuber bulking, early maturity, high number of tubers per plant and high yield performance are all vital characters for both the small holder and large scale farmers for tackling food insecurity. This variety has multiple resistance to many of the major diseases in potato growing areas in Kenya which includes high horizontal resistance to late blight, resistance to PVY and PLRV and is moderately susceptible to leaf miner flies. With the recent climate change and the emerging new complex strains of pathogens, release of variety Sherekea with durable and multiple resistances to a variety of diseases is an asset in case of future disease outbreaks and the subsequent food security risk involved. Growing late blight tolerant variety like Sherekea is economical and environmentally friendly since it require less fungicide sprays (maximum of 2 fungicide sprays) instead of 6 or more in susceptible varieties like Dutch Robjin to produce an economical crop. Among the attributes that are demanded by the Kenyan market and consumers includes its very high yields, multiple resistance to economically important potato diseases, attractive red skin colour with good storability, good quality chips, crisps and table boiled or mashed potato and high dry matter content (21.9 $\%)$. The many different ways of utilization will make it fit all types of consumers.

Variety Kenya Mpya (393371.58): Kenya Mpya is a medium-sized potato plant with strong semi erect stems, light green medium sized leaves, medium number of tubers per plant, white flowers with a regular flowering habit. In the field, the variety produces a vigorous crop with good ground cover. In the DLS, the new variety produces sprouts at between 75 to 90 days (short dormancy). Short dormancy in Kenya Mpya will enable farmers to get good sprouts to catch up with the two planting seasons of the year. Farmers have been lacking a reliable and sustainable method of breaking dormancy (Gachanjo et al., 2008) making many farmers to rely basically on traditional early sprouting varieties (Muthoni et al., 2010). To bulk ware size tubers and reach full physiological maturity, the variety takes between 90 to 105 days (early maturing). Early maturity and early tuberization in Kenya Mpya makes it a suitable variety in case of reduced rainfall. In case of famine or natural calamities, this variety will provide food after a short period of time. This variety has also strong horizontal resistance to late blight, extreme resistance to PVX, resistance to PVY and moderately susceptible to leaf miner flies. It will require less agrochemical inputs to grow due to multiple resistance to important pests and diseases making it economical and sustainable to produce the crop. The variety is highly adapted in many potato growing areas in Kenya and for optimum production, cool, moist, mid-highlands and an altitude ranging 1,400 to 3,000 m.a.s.I is recommended. Under optimum production conditions and with recommended agronomic practices, variety Kenya Mpya has the potential of producing high yields which range from 35-45 T/ha. This is the highest yield range in the most improved varieties apart from that of variety Sherekea which is between 40-50 T/ha. The variety produces good quality chips, crisps and is also good for boiling and mashing and has high dry matter content $(22.5 \%)$. Attractive big oval cream skin colored tubers with pink splashed eyes, shallow eye depth in addition to its good cooking and processing quality are essential for its marketability and consumption.

Variety Purple Gold (391691.96): Purple Gold is distinguished by it's oval shape, dark purple skin colour and medium to large size tubers. The variety exhibits between tuberosum and andigena growth habit (medium size plant) with semi-erect strong stems, small to medium size leaves, purple flower colour and regular flowering habit. Though not very high yielding (25-35 $\mathrm{T} / \mathrm{ha}$ ), Purple Gold is mealy with a dry matter content of $21.4 \%$ and has better crisping quality than Dutch Robjin which is currently the mist popular crisping variety. Apart from crisping. Purple Gold is also good for chipping, mashing, boiling and roasting. The variety is moderately resistant to late blight, resistant to PVX, susceptible to PVY, moderately resistant to PLRV, tolerant to most soil borne diseases and moderately susceptible to leaf miner fly. The multiple resistance and the higher level of resistance to pest and diseases make it a more competitive alternative crisping variety compared to Dutch Robyjn. Though Purple Gold has long dormancy 
of 90-105 days and long maturity period of 120-135 days, its good storability will benefit traders who will want to maintain a constant supply to the market over a long period of time with minimized post harvest losses. The optimal production altitude for Purple Gold is wide, ranging from between 1800-3000 m.a.s.I though it does best in the cool highlands.

Seed availability of the new varieties: The three clones, namely: $393385.39,393371.58$ and 391691.96 were released as new varieties and named Sherekea, Kenya Mpya and Purple Gold respectively on $17^{\text {th }}$ May 2010 by the Kenya National Variety Release Committee. The disease-free seed stocks of the new varieties are maintained in in-vivo or in-vitro form at KARI, National Potato Research Centre (NPRC), Tigoni. Request for seed tubers of the new varieties can be channeled through: The KARI Seed Unit, NPRC, Tigoni, P.O. Box 338-00217 Limuru or the International Potato Centre (CIP), P.O. Box 25171, Nairobi, Kenya.

\section{ACKNOWLEDGEMENTS:}

This study was supported by KARI and CIP, SubSaharan Africa office. We appreciate the support from individuals and institutions (Mr. Cheruiyot-Narok; Mr. Marangu-Kibirichia; Mr. Kairu-Limuru; KARI- OJK; Kisima Farm-Timau; Agricultural Development Corporation-Molo and Baraka Agricultural Training Centre -Molo). We also thank Deepa Industries, Nairobi for their good collaboration.

\section{REFERENCES}

Campbell, C.L and Madden, L.V (1990). Introduction to plant disease epidemiology. John and Wiley and Sons, Inc., New York, USA. pp 246-248

El-Bedewy, R., Olanya M., Adipala E., Ewell P., Kabira J., Walingo A., Lungaho C., Hakiza J. J., Wagoire W., Kahuhenzire R., Anginyah P., Ojiambo P.S and Nakitandwe $J$ (2001). Performance of potato genotypes and resistance of Phytophthra infestants in Standard International Field Trials in selected locations in East Africa. African Crop Science Conference Proceedings 5:461-468.

Fry W.E., Thurdson H. D and Stevenson, W.R (2001). Late blight. Pages 28-30. In: Compendium of potato diseases, $2^{\text {nd }}$ eds (Stevenson, W.R., Loria R., Franc, G.D and Weingartner, D.P). American Phytopathological Society Press. St. Paul M.N.

Gachango E., Shibairo S. I., Kabira J. N., Chemining'wa G. N and Demo $P$ (2008). Effects of light intensity on quality of potato seed tubers. African Journal of Agricultural Research Vol. 3 (10), pp. 732-739

Kabira J. N., Wakahiu M., Wagoire W., Gildermacher P and Lemaga B (2006). Guidelines for production of healthy seed potatoes in East and Central Africa. Kenya Agricultural Research Institute, Nairobi.
Khurana, S.M (2000). Potato viruses: Detection and management .African Potato Association. In: Proceedings of the fifth Triennial Congress of the African Potato Association, Kampala Unganda $29^{\text {th }}$ May- $2^{\text {nd }}$ June 2000. Vol. 5.Pp 257-269.

Landeo J. A., Gastelo M., Forbes G., Zapata J. L and Forbes F. J. (1997). Developing horizontal resistance to late blight in potato. CIP Program Report.1995-1996. pp 122-126.

Landeo J. A., Gastelo M., Roncal E and Mendoza A (2000). Phenotypic stability for horizontal resistance to potato late blight in population B. American Journal of Potato Research 77:406

Lawes (1995). Lawes Agricultural Trust, Rothamsten Experimental Station, 1995.

Lung'aho C., Nderitu S. W. N., Kabira J. N., EL-Bedewy R., Olanya O. M and Walingo A (2006). Yield performance and release of four late blight tolerant varieties in Kenya. Journal of Agronomy 5(1): 57-61, 2006. Asian Network for Scientific Information. pp 57-61.

Lung'aho C., Chemining'wa G., Shibairo S and Hutchinson M (2008). Reaction of potato cultivars to natural infestation of late blight caused by Phytopthora infestants in Kenya. East Africa Agriculture and Forestry Journal 74 (3) pp 195-200.

MoA (2005). Potato Industry Strategic Plan 2005-2014. Ministry of Agriculture, strategy for developing potato industry In Kenya, August 2005. pp 1-34.

MOA/GTZ-PSDA (2009). National Potato Taskforce Report 2009. Final Report. pp 1-10.

MoA/GTZ-PSDA/CIP/USAID (2009). Seed Potato Subsector in Kenya. Five Year Master Plan (2009-2014), September 2009. Government of Kenya MoA/GTZ-PSDA/CIP/USAID. pp 1-36.

Muthoni J, Mbiyu M and Nyamongo D.O (2010). A review of potato seed systems and germplasm conservation in Kenya. Journal of Agriculture and Food Information 11:2, pp 157-167.

Nakitandwe J., Adipala E., El-Bedewy R., Wagoire W and Berga $L$ (2005). Resistance to late blight and yield of population B3 potato selections in Uganda. African Crop Science Journal, Vol. 13. No2. pp 95-105

NPRC (2008). National Potato Research Centre, Annual Report 2008. pp 1-4.

Olanya O .M., Adipala E., Hakiza J. J., Kedera C., Ojiambo P. S., Mukalazi J. M., Forbes G and Nelson R (2001). Epidemiology and population dynamics of Phytpthora infestants in Sub-Saharan Africa: Progress and Constraints: African Crop Science Journal 9:185-193.

Simons, M. D (1972). Polygenic resistance to plant disease and its use in breeding resistant cultivars. Journal of Environmental quality 1: 232-240.

Steel, R. G .D and Torrie, J. H (1980). Principles and procedures of statistics. A biometrical approach $.2^{\text {nd }}$ edition. McGraw and Hill Inc. pp 86-191. 